\title{
TRADISI KISIK-KISIK DALAM MASYARAKAT MUSLIM TANJUNGBALAI ASAHAN
}

\author{
Husnel Anwar Matondang \\ Fakultas Ushuluddin dan Studi Islam UIN Sumatera Utara \\ J1. Willem Iskandar Pasar V Medan Estate, Sumatera Utara, 20371 \\ e-mail: husnelanwarmatondang70@gmail.com
}

\begin{abstract}
Abstrak: Masyarakat Tanjungbalai Asahan sebagai pelaku ritual kisik-kisik mempercayai bahwa penyakit yang diderita oleh manusia selalu dipahami dalam dua sisi yang saling mempengaruhi, yakni penyakit pada jasad dapat mempengaruhi jiwa (batin/ ruh) dan penyakit pada jiwa (batin) dapat pula mempengaruhi kesehatan jasad (badan). Solusi magis yang digunakan masyarakat ini adalah kisik-kisik, yaitu suatu upacara untuk memanggil sumangat (ruh) yang telah hilang atau pergi dari jasad seseorang yang menderita sakit agar ia kembali sehat. Dalam menjelaskan sistem kepercayaan kisik-kisik digunakan teori fungsionalis Bronislaw Malinowski, yaitu masyarakat dilihat sebagai suatu totalitas fungsional, seluruh adat kebiasaan dan praktik harus dipahami dalam totalitas konteksnya dan dijelaskan dengan melihat fungsinya bagi anggota masyarakat yang diteliti. Dari kajian ini, ditemukan bahwa ritual kisik-kisik berawal dari kepercayaan animisme yang menjadi anutan nenek moyang orang-orang Tanjungbalai Asahan. Namun, ia tetap dipraktikkan, kendati mereka telah memeluk Islam.
\end{abstract}

\begin{abstract}
Kisik-Kisik Tradition in Tanjung Balai Muslim Community. Tanjungbalai Community in Asahan as the actors of kisik-kisik ritual believe that the diseases suffered by humans always understood in two sides of interaction, that is the bodies diseases may affect the psyche (mind/spirit) and the soul diseases (mind) can also affect the bodies healthy (bodies). The magic solution that allows people is kisik-kisik, that is a ceremony to call spirit (ruh) that have been lost or away from the body of person who is sick to become healthy. In explaining the system of kisikkisik belief used functionalist theory by Bronislaw Malinowski, that society is seen as a functional totality, the entire customs and practices must be understood in totality context and explained by looking at the function for the communities who studied. From this study, it was found that the kisik-kisik ritual came from animism which became an ancestor's belief of Tanjungbalai people in Asahan. However, it still practiced, although Tanjungbalai people have embraced Islam.
\end{abstract}

Kata Kunci: kisik-kisik, ritual, penyembuhan, Tanjungbalai, Asahan 


\section{Pendahuluan}

Tanjungbalai Asahan adalah salah satu daerah tingkat dua di propinsi Sumatera Utara. Etnis asli yang mendiami Tanjungbalai Asahan adalah etnis Melayu dan Batak yang sebagian besarnya beragama Islam. ${ }^{1} \mathrm{Di}$ samping etnis tersebut, terdapat juga beberapa etnis lainnya seperti, Jawa, Aceh, Minang, India, ${ }^{2}$ dan Tionghoa yang beragama Konghucu dan Buddha. Namun, etnis Melayu merupakan motor utama penggerak roda kebudayaan di Tanjungbalai Asahan. Oleh sebab itu, perilaku budaya secara umum yang ditampilkan di daerah ini selalu merepresentasikan dan mengatasnamakan Islam, karena telah menjadi adagium di kawasan ini bahwa Melayu sama dengan Islam.

Kendatipun agama Islam telah lama dianut oleh penduduk Tanjungbalai Asahan, tetapi banyak ditemukan ritual-ritual yang berasal dari ajaran animisme yang terus tumbuh. Tradisi orang-orang Islam yang khas inilah yang disebut oleh Robert Redfield sebagai little tradition ${ }^{3}$ yang membedakan keislaman masyarakat Tanjungbalai Asahan dengan masyarakat Muslim di daerah lainnya. Salah satu di antara tradisi khas itu adalah ritual Kisik-kisik yang dilakukan sebagai media penyembuhan.

Kisik-kisik secara antropologis dapat dipahami sebagai sistem kepercayaan yang dianut oleh masyarakat Tanjungbalai Asahan, khususnya di daerah Sei Tualang Raso dan daerah-daerah pinggir laut lainnya, yang terkait dengan magis. Ritual itu dilakukan ketika seseorang dari anggota masyarakat diterpa penyakit yang tidak kunjung sembuh, yaitu setelah dilakukan pengobatan melalui jasa tabib, ramuan-ramuan tradisional, atau jasa kedokteran. Ritual ini terkadang dilakukan secara mandiri dan terkadang dilakukan bersama dengan ritual lainnya seperti ritual jungkit-jungkit, ${ }^{4}$ dan manyonggot. ${ }^{5}$

${ }^{1}$ Orang Batak merupakan etnis kedua yang menempati posisi penting setelah etnis Melayu, baik dari segi partisipasi pembangunan daerah maupun kebudayaan. Karena banyaknya etnis ini di Tanjungbalai Asahan, maka ada kesan bahwa Melayu Tanjungbalai merupakan orang Batak yang berkhitan (memeluk Islam). Istilah masuk Islam itu disebut juga dengan "masuk Malayu." Kesultanan Tanjungbalai dimulai dari kisah Raja Si Margolang dan Sultan Iskandar Muda dari Aceh. Dari sinilah awal berdirinya kesultanan Tanjungbalai. Lihat Mohamad Arsyad, Tabal Mahkota Negeri Asahan (t.t.p.: t.p., 1933), h. 1-43.

${ }^{2}$ Bukti historis tentang orang-orang India di Tanjungbalai Asahan dapat dilihat hingga saat ini seperti pertokoan Jaganath Son. Sebuah grosir penjualan kain dan bahan-bahan pakaian dari hasil tekstil India.

${ }^{3}$ Ronald A. Lukens Bull, "Between Text and Practice: Considerations in the Antrophologycal Study of Islam," dalam Marburg Journal of Religion, Vol. 4, No. 2, December, 1999, h. 5-7.

"Jungkit-jungkit adalah ritual penyembuhan melalui telur ayam dan daun tumbuh-tumbuhan yang digosokkan ke badan orang yang sakit. Wawancara dengan Dek Ipin, tanggal 15 Desember 2008.

${ }^{5}$ Manyonggot adalah upacara untuk mengembalikan kekuatan jiwa (sumangat) seseorang yang diterpa musibah atau acara-acara penghormatan seperti berangkat haji, khitanan, atau khataman al-Qur'an. Acara ini dilakukan dengan melakukan upah-upah, yaitu membawa balai [wadah bersegi empat] yang di dalamnya diisi dengan pulut ketan yang diwarnai dengan warna kuning, sedangkan yang terkait dengan keagamaan seperti melakukan upah-upah untuk acara 
Perilaku ritual Kisik-kisik tersebut menarik untuk dikaji karena dua hal. Pertama, pada era modernisasi, termasuk di kawasan Tanjungbalai Asahan saat ini, pengobatan magis seperti Kisik-kisik masih dipercayai masyarakat dapat menyembuhkan penyakit. Lebih jauh lagi, hal itu menjadi kepercayaan dari segala lapisan sosial, tidak saja masyarakat awam tetapi juga orang-orang yang terpelajar. Kedua, Islamisasi yang telah berlangsung berabad-abad di daerah ini tidak mampu mengikis ritual-ritual animisme dengan tuntas, bahkan yang terjadi adalah adaptasi dan elaborasi. Melihat kenyataan ini, diharapkan untuk melakukan kajian mendalam tentang keberadaan Kisik-kisik tersebut dari sudut eksistensinya sebagai upaya penyembuhan di dalam masyarakat Tanjungbalai Asahan.

Masalah yang ingin diteliti dalam kajian ini adalah segala sesuatu yang terkait dengan pemaknaan Kisik-kisik oleh masyarakat Tanjungbalai Asahan dengan melihat fungsinya bagi masyarakat dan apa tujuan-tujuan yang ingin dicapai. Ritual-ritual magis tersebut dipahami sebagai sebuah sistem kepercayaan masyarakat untuk memenuhi kebutuhan kesehatan dan keselamatan yang tidak bisa diprediksikan.

\section{Metode Penelitian}

Penelitian ini merupakan penelitian deskriptif analitis dengan menggunakan pendekatan antropologi (anthropological approach). Hal tersebut dilakukan secara intensif di seluruh kajian ini. Oleh sebab itu, di dalam kajian ini tidak akan ada penilaian yang bersifat teologis atau agama untuk membenarkan atau menyalahkan kepercayaan objek kajian. Dikecualikan dari objektivitas kajian, pada saran-saran disarankan agar sesuatu yang bersifat ideal keagamaan yang seyogianya dimiliki kaum Muslim Tanjungbalai Asahan. Namun hal ini tidak memengaruhi kajian dan hasil kajian sehingga objek (sebagai data) berbicara sendiri.

Dalam menjelaskan sistem kepercayaan Kisik-kisik tersebut digunakan teori fungsionalis Bronislaw Malinowski, yaitu masyarakat dilihat sebagai suatu totalitas fungsional. Seluruh adat kebiasaan dan praktik harus dipahami dalam totalitas konteksnya dan dijelaskan dengan melihat fungsinya bagi anggota masyarakat yang diteliti. ${ }^{6}$ Oleh sebab itu, Kisik-kisik di dalam kajian ini akan dijelaskan dengan melihat fungsinya bagi masyarakat dan apa tujuantujuan yang ingin dicapai. Ritual-ritual magis tersebut dipahami sebagai sebuah sistem

pemberangkatan haji, khataman Alquran, atau khitanan tidak diberi warna (warna putih). Di atas pulut ketan tersebut disisipkan mara-wal (bendera kecil yang terbuat dari kertas atau sejenisnya dan ditebuk sedemikian rupa) dan telur ayam, yang juga dibungkus dengan kertas yang berukir. Warna mara-wal dan pembungkus telur ayam tersebut disesuaikan dengan warna pulut ketannya. Husnel Anwar Matondang, Kewajiban Tuhan: Pemikiran Kontroversial Ulama Tanjungbalai Asahan Syaikh Ismail Abdul Wahhab (Medan: LP2IK, 2004), h. 18. Bandingkan juga upa-upa di dalam tulisan Nalom Siahaan, Adat Dalihan Natolu: Prinsip dan Pelaksanaannya (Jakarta: Tulus Jaya, 1982), h. 81.

${ }^{6}$ David C. Gellner, "Pendekatan Antropologis," dalam Peter Connolly (ed.), Aneka Pendekatan dalam Studi Agama (Amerika: Continuum, 1999), h. 25-26. 
kepercayaan masyarakat untuk memenuhi kebutuhan kesehatan dan keselamatan yang tidak bisa diprediksikan. Di dalam A Scientific Theory ofCulture Other Essays, Bronislaw Malinowski mengatakan bahwa ada tujuh bidang kebutuhan dasar masyarakat, yaitu metabolisme, reproduksi, kesenangan fisik, keamanan, gerakan, pertumbuhan, dan kesehatan. ${ }^{7}$ Pada bagian kesehatan dan keamananlah kajian ini mengambil peran objektifnya.

Untuk menjelaskan hal-hal yang terkait dengan magis tersebut, juga merujuk kepada penjelasan-penjelasan Bowen tentang Magic and Healing di dalam bukunya Religions in Practice: An Approach to the Anthropology of Religion. ${ }^{8}$ Di sini juga dilihat bagaimana magis dipahami dan dibedakan dari ajaran agama yang dianut oleh subjek budaya.

Pada sisi yang lain, digunakan teori Marx untuk menjelaskan kasus mengapa para dukun mempertahankan kepercayaan ritual Kisik-kisik dalam kehidupan masyarakat, sehingga sampai kepada sebuah hipotesis bahwa hal itu disebabkan faktor desakan ekonomi. Marx berpendapat bahwa mempertahankan sebuah sistem kepercayaan memiliki motif-motif ekonomi. Namun disadari bahwa Kisik-kisik tidaklah dipahami oleh masyarakat Tanjungbalai Asahan sebagai sebuah ajaran agama, melainkan hanya sebuh kepercayaan magis. Meski demikian, sebagai sebuah sistem kepercayaan, Kisik-kisik telah dimanfaatkan oleh para dukun untuk mendapatkan keuntungan. Dengan melanggengkan ritual ini, mereka mendapat bayaran untuk memenuhi kehidupannya. Pada konteks terakhir inilah dipakai teori Marx sebagai pisau analisis.

Sumber data dalam penelitian ini adalah penduduk Tanjungbalai Asahan yang melaksanakan ritual Kisik-kisik dan para dukun yang menggerakkan ritual-ritual tersebut. Selanjutnya dilakukan wawancara kepada 3 orang dukun Kisik-kisik dan para penggiat dan pengamalnya. Di samping itu juga telah diamati bahwa ritual ini lebih dari 10 kali di dalam rentang waktu 10 tahun, sehingga kajian ini juga termasuk observasi partisipan yang selalu disarankan oleh Bronislaw Malinowski.

\section{Hasil dan Pembahasan}

\section{Mengenal Kisik-kisik}

Pengertian

Kisik-kisik merupakan bahasa Melayu Asahan yang tidak ditemukan di dalam bahasa Melayu lainnya di Nusantara. Secara etimologi, Dek Ipin salah seorang tokoh pemuda Tanjungbalai Asahan mengatakan bahwa Kisik-kisik tidak memiliki arti etimologis kecuali

${ }^{7}$ Malinowski, A. Scientific Theory of Culture Other Essays (Amerika: Universiti of North California Press, 1994), h. 91.

${ }^{8}$ John R. Bowen, Religions in Practice: an Approach to the Anthropology of Religion (Amerika: Washington University in St. Louis, t.t.), h. 67. 
dipahami untuk makna ritual mistis mengembalikan sumangat (spirit) ke dalam jasad orang yang sakit atau orang yang tidak memiliki gairah hidup. ${ }^{9}$

Dalam pemahaman masyarakat Tanjungbalai Asahan, Kisik-kisik adalah sebuah upacara atau ritual untuk memanggil atau mengembalikan sumangat (roh) yang telah hilang atau pergi dari jasad seseorang yang menderita sakit. Sumangat itu dapat kembali lagi ke dalam jasad penderita ketika ia diseru atau dibujuk untuk kembali dengan suatu ritual tertentu. Hal ini sebagaimana yang dikemukakan oleh Wak Acom salah seorang tabib kampung di daerah Sungai Tualang Raso Tanjungbalai Asahan. Ia berkata, “Oilah! Kisik-kisik tu kan manjomput sumangatnyo itu. Okhang nan takojut nan sakit, sumangatnyo pogi. Makonyo dibuatlah Kisik-kisik agakh sumangattu maulah dio belek ka badan okhang nan sakit tu dan botahlah panyakit-panyakit nan ado di badantu." (Kisik-kisik adalah (ritual) menjemput (memanggil) sumangat (roh). Orang yang terkejut dan sakit, sumangatnyo meninggalkan jasad orang tersebut. Maka (ritual) Kisik-kisik dilakukan agar sumangat tersebut kembali ke dalam jasad orang yang sakit; dengan kembalinya sumangat tersebut maka sembuhlah penyakit yang terdapat di badan orang yang sakit). Dari ungkapan di atas dipahami bahwa Kisik-kisik adalah suatu sistem kepercayaan yang dianut oleh masyarakat Tanjungbalai Asahan yang bertujuan pada sebuah tujuan untuk menyembuhkan penyakit orang yang sakit atau kehilangan gairah hidup. Sebagaimana yang dikatakan Malinowski, kesembuhan dari suatu penyakit merupakan salah satu tujuan magis, yaitu untuk menghasilkan beberapa akibat spesifik seperti kesembuhan tersebut. ${ }^{10}$

Masyarakat Tanjungbalai Asahan memercayai bahwa penyakit yang diderita oleh seseorang selalu dipahami dalam dua sisi yang saling memengaruhi. Pertama, penyakit pada jasad dapat memengaruhi jiwa (batin/roh). Kedua, penyakit pada jiwa (batin) dapat pula memengaruhi kesehatan jasad (badan). Sakit pada jasad (badan) seseorang seperti luka disebabkan kecelakaan kerja, kecelakaan transportasi dan perkelahian diobati secara medis atau obat-obatan dan ramuan-ramuan tradisional yang dikenal dengan pengobatan alternatif. Namun, sakit disebabkan jasad tersebut dapat pula memengaruhi pada keberadaan jiwa (sumangat). Dengan kata lain, sumangat bisa terganggu karena penyakit yang diderita jasad. Oleh sebab itu, pengobatan jiwa juga harus dilakukan mengiringi pengobatan penyakit pada jasad (badan).

Demikian pula, ketika seseorang menderita sakit disebabkan unsur-unsur gaib seperti sakit karena gangguan jin, orang halus, ${ }^{11}$ dan guna-guna (sihir), maka dilakukan pengobatan ritual khusus untuk menyembuhkannya di samping pengobatan Kisik-kisik. Seiring dengan itu dilakukan juga pengobatan medis atau obat-obatan tradisional untuk mengobati jasad

${ }^{9}$ Wawancara dengan Dek Ipin pada tanggal 15 Desember 2005.

${ }^{10}$ Lihat lebih jauh uraian david N. Gellner, "Pendekatan Antropologis," h. 27.

${ }^{11}$ Orang halus adalah sebangsa makhluk gaib (jin) yang dapat menjelma sebagai manusia dan secara tidak diketahui ikut dalam kegiatan manusia. Wawancara dengan Ummi Normah pada 15 Desember 2008. 
yang sudah lemah karena sakit yang diderita seseorang. Dengan demikian, masyarakat Tanjungbalai Asahan selalu memadukan pengobatan secara medis dan pengobatan secara magis melalui dukun atau tabib bagi orang yang sakit. Namun, penekanan ritual Kisikkisik hanya dilakukan ketika seseorang kehilangan gairah hidup, baik itu disebabkan sakit batin maupun sakit fisik.

\section{Tata Cara Pelaksanaan Kisik-kisik}

Kisik-kisik dapat dilakukan bersamaan dengan ritual jungkit-jungkit, ritual manyonggot, dan dapat pula dilakukan secara mandiri. Hal itu tergantung kepada besar kecilnya penyakit dan lamanya orang yang sakit serta penilaian seorang tabib atau dukun yang dipercaya. Dalam pada itu, ritual Kisik-kisik juga dilakukan secara beragam tergantung dengan penyakit gaib (batin) yang diderita oleh orang yang sakit dalam pandangan seorang tabib atau dukun. Demikian juga ritual tersebut dapat berbeda antara satu dukun dengan dukun yang lainnya. Namun perbedaan itu tidak terlalu jauh. Perbedaan itu dimungkinkan karena perbedaan guru yang mengajarkan atau perbedaan informasi gaib yang mereka terima.

Umumnya penyakit yang terkait dengan kehilangan sumangat bagi seseorang adalah hilangnya sumangat karena terkejut, shok, mendayu-dayu (berkecil-hati karena keinginan tidak tercapai atau kehilangan gairah), dizalimi orang lain, hilangnya sumangat karena takono (disakiti oleh jin atau orang halus). Dalam kepercayaan masyarakat Tanjungbalai Asahan, jin dan orang halus dapat menyakiti seseorang disebabkan ia diganggu, baik pribadi, tempat tinggal, atau pun keluarga jin dan orang halus tersebut; hilangnya sumangat karena disihir atau diguna-gunai orang lain, seperti penyakit gelang-gelang, polong, atau guno-guno; dan hilangnya sumangat karena kecelakaan kerja atau perkelahian.

\section{Tabib dan Dukun}

Tata cara pelaksanaan Kisik-kisik di dalam masyarakat Tanjungbalai Asahan dimulai dengan memanggil tabib atau dukun. Di daerah ini ada kesan bahwa tabib dan dukun dapat dibedakan, namun belakangan ini pembagian itu sudah mulai memudar. Tabib umumnya adalah orang yang mampu mengobati dengan ramuan-ramuan tradisional dan juga memiliki kemampuan mengobati penyakit gaib (mistis) dengan melakukan islamisasi mantra. Sementara itu, dukun adalah orang yang mampu mengobati dengan jampi-jampi tanpa melakukan islamisasi mantra-mantranya. Namun, terkadang para pengobat gaib itu dibagi pula ke dalam pembagian dukun putih dan dukun hitam. Orang yang mengusung islamisasi mantramantra pengobatan disebut dengan dukun putih. Misalnya, dengan memulai membaca bismillah dan salawat kepada Nabi Muhammad SAW. dan mengucapkan mantra dengan sifat-sifat Allah. Sebagai contoh, mantra pelaris dan pemanis, "nukh manjadi sifatulloh, sifat manjadi kalamulloh, hai matohakhi takh pancakhlah diubun-ubunnyo, dio tapandang samuo khajo, dio tapandang samuo sultan-sultan, dio tapandang sakalion manusio, qobul 
bakhkat lailaha illolloh Muhammadukhkhsulullah. Sementara itu, dukun hitam adalah orang yang tetap mempertahankan mantra-mantra nenek moyangnya tanpa melakukan islamisasi. Di antara mantra tersebut ada yang berasal dari mantra batak dan suku lainnya di samping bahasa Melayu Tanjungbalai Asahan. Sebagai contoh dapat dilihat di dalam mantra obat katoguran, ${ }^{12}$ "pus sahoting tak bulung gaol tak bulung boti muliho begu songgop." Di antara dukun putih dan dukun hitam dapat juga dibedakan dengan ciri-ciri perilaku dan penampilannya.

Dukun putih laki-laki biasanya menggunakan lebai atau peci dan sering pula memakai pakaian-pakaian ala ulama. Dukun putih wanita biasanya menggunakan kerudung penutup kepala untuk menyembunyikan (menutup) sebagian auratnya. Sementara itu dukun hitam laki-laki kerap menggunakan pakaian warna hitam atau pakaian-pakaian yang tidak mencirikan kesalehan atau keulamaan. Sementara itu, dukun hitam wanita ditandai pakaian yang tidak mencirikan kesalehan seperti tidak menutup aurat. Namun terkadang ada juga dukun hitam wanita yang menggunakan kerudung, tetapi kerudung itu hanya dililitkan di kepalanya. Dalam hal perilaku, dukun putih tidak melakukan kezaliman kepada orang lain. Ia tidak mau disuruh memulai untuk mengirim penyakit gaib kepada orang lain seperti penyakit polong, golang-golang, atau santet. Sementara itu dukun hitam biasanya mau menerima suruhan tersebut. Terkadang, dukun putih juga melakukan sembahyang hajat untuk membalas kezaliman yang dilakukan oleh orang lain atau dukun hitam kepadanya atau kepada seseorang yang menderita sakit. Tujuannya agar penyakit itu kembali lagi kepada orang yang mengirim penyakit gaib tersebut, sehingga terjadilah pertarungan mistik antara dukun putih dengan dukun hitam. Pertarungan ini terkadang diklaim dapat menyebabkan kematian atau sakit parah dan berkepanjangan.

Khusus untuk ritual Kisik-kisik, tabib atau dukun yang melaksanakannya adalah wanita. Seperti yang diamati selama sepuluh tahun di daerah Tanjungbalai Asahan, tidak pernah dijumpai laki-laki yang melaksanakan ritual Kisik-kisik tersebut. Biasanya juga yang menjadi tabib atau dukun itu adalah wanita-wanita yang sudah memiliki usia di atas 50 tahun.

\section{Mempersiapkan Ramuan}

Untuk menjelaskan hal ini, langsung diamati proses pra ritual Kisik-kisik dilakukan. Sebelum tabib atau dukun datang ke rumah orang yang akan melakukan ritual Kisikkisik, maka tuan rumah sudah menyiapkan alat-alat atau ramuan-ramuan yang akan dipergunakan oleh sang tabib atau dukun. Di antara ramuan itu adalah dupa (wadah yang terbuat dari batu atau lainnya untuk tempat membakar kemenyan). Di dalam dupa itu dimasukkan bara api, kayu arang dan kemenyan. Kemenyan yaitu sebangsa getah kayu yang sudah membeku. Ketika dibakar akan memberikan aroma wangi yang khas. Khusus

\footnotetext{
${ }^{12}$ Penyakit yang disebabkan oleh sapaan ruh orang yang sudah meninggal atau teguran jin.
} 
untuk ritual Kisik-kisik, kemenyan yang dipergunakan adalah kemenyan putih, sirih bertemu urat tiga helai, yaitu daun sirih yang ruas-ruas (gurat-guratannya) bertemu di ruas tulangnya, kencur, bawang merah, kapur, buah pinang, dan gambir, benang jahit yang sudah dimasukkan ke dalam lubang jarum jahit, dan mangkok putih yang sudah dipenuhi beras dan di tengahtengahnya diletakkan telur ayam kampung (ras). Sebagian dukun mewajibkan meletakkan uang koin sebanyak tujuh buah yang disusun melingkari telur ayam di atas beras tersebut. Penambahan ini misalnya terdapat pada seorang dukun yang bernama Incek Nurbi. Ia menjelaskan, "Kisik-kisik hakhus pakek duit logam tujuh buah" (Kisik-kisik harus menggunakan uang koin tujuh buah). ${ }^{13}$

Kalau orang yang sakit itu dihinggapi penyakit demam panas atau semisalnya, maka disediakan pula alat-alat tambahan. Namun hal ini perlu dideteksi sebelumnya oleh sang dukun atau tabib, apakah penyakit seseorang itu disebabkan takono (disakiti oleh jin atau orang halus) atau karena hanya terkejut dan demam biasa. Jika sakitnya disebabkan takono berdasarkan kesimpulan dukun atau tabib setelah berkomunikasi dengan alam gaib atau dari bisikan jin peliharaannya atau berdasarkan tenungannya, barulah ramuan-ramuan tambahan itu disediakan. Biasanya jika kesalahan terhadap jin atau orang halus tersebut kecil, maka cukup dengan menyediakan bunga tujuh rupa, daun sirih bertemu urat sebanyak tujuh helai, ditambah lagi daun sirih lainnya, dan tujuh macam duri tumbuhan. Di dalam daun sirih bertemu urat itu ditaburkan gambir, kapur sirih, buah pinang, dan irisan kayukayu keras, seperti kayu ara dan kayu sepang. Terkadang juga diikutsertakan rokok daun satu gulungan tembakau yang diselipkan di dalam setiap lembaran sirih tersebut yang panjangnya sekitar 5 inci. Sirih tersebut terlebih dahulu ditaburkan kapur, buah pinang, gambir, dan serbuk kayu-kayuan.

Ketika kesalahan seseorang itu terhadap jin dan orang halus tersebut tergolong besar, maka harus disedikan apa yang diminta oleh sang tabib atau dukun tersebut. Biasanya yang diminta adalah ayam jantan berwarna hitam atau putih atau merah atau ayam tigo wakhno (tiga warna). Jika kesalahannya sangat besar, maka sang dukun terkadang meminta seekor domba atau kambing atau sesuatu yang lebih besar dari itu. Namun, untuk yang terakhir ini, masyarakat jarang yang memenuhinya, karena harganya terlalu mahal. Mereka menyuruh dukun untuk bernegosiasi dengan jin atau orang halus tersebut agar diganti dengan persembahan yang lebih kecil lagi. Selain itu, dukun juga bisa meminta untuk dibuatkan lancang kuning, ${ }^{14}$ jika jin atau orang halus tersebut berada di sungai atau di laut. Jin ini disebut mambang laut. Namun jika di daratan, sesajennya cukup dibuat hanya semacam hidangan (sajian).

Adapun, jika penyakit seseorang itu hanya kehilangan sumangat tanpa diiringi sakit yang lain, maka cukup dengan melakukan ritual Kisik-kisik biasa. Sebagaimana yang

\footnotetext{
${ }^{13}$ Wawancara dengan Incek Nurbi dan Kak Acom pada 16 Desember 2008.

${ }^{14}$ Lancang kuning adalah sesajen yang ditempatkan di dalam wadah yang berbentuk sampan atau perahu layar. Di dalamnya diisi dengan sesajen.
} 
disebutkan di atas, ketika seseorang yang kehilangan sumangat itu diiringi sakit seperti demam disebabkan selain sakit takono, maka disediakan pula sedikit tambahan dari kisisk-kisik biasa. Pengobatan tambahan ini disebut jungkit-jungkit. Baik pada Kisik-kisik untuk ritual karena terkejut atau karena takono, pihak keluarga yang sakit harus menyediakan benang tiga warna, yaitu hitam, kuning, dan putih atau merah, kuning dan hitam, atau merah, putih, dan kuning. Benang tersebut dipintal menjadi semacam tali untuk dijadikan gelang. Terkadang juga dapat digunakan benang tanpa berwarna-warni, namun harus dipilih warna putih.

Ramuan tambahan untuk penyakit kehilangan sumangat yang diringi penyakit, seperti demam disebabkan selain sakit takono adalah mangkok putih berisi air, telur ayam, dan daun kunyit bungle, akar jariango, dan daun pepaya. Kemudian, jika penyakit seseorang itu dianggap cukup berpengaruh kepada hilangnya sumangat atau jauhnya sumangat seseorang dan payah kembali, maka ritual tambahan yang harus dilakukan yaitu manyonggot. Manyonggot adalah suatu peristiwa ritual yang memberikan kejutan kepada orang yang sakit atau orang yang kehilangan sumangat disebabkan suatu kejadian besar yang menimpanya. ${ }^{15}$ Kejutan itu adalah berbentuk datangnya para keluarga dan tetangga dalam jumlah besar ke rumah orang yang sakit dengan membawa balai dan makanan-makanan, khususnya pulut ketan dan inti (parutan buah kelapa dicampur gula merah/aren). Kedatangan rombongan ini tidak diberitahukan sebelumnya kepada orang yang sakit agar ia terkejut atas kedatangan tiba-tiba itu. Ketika sampai di rumah orang yang sakit, maka terkadang dilakukan ritual Kisik-kisik dan upah-upah. ${ }^{16}$ Untuk upah-upah ini, pihak keluarga di rumah tidak menyediakan apapun. Semua keperluan Kisik-kisik dan menyonggot itu dibawa oleh keluarga yang datang memberikan kejutan.

\section{Melangsungkan Ritual Pengobatan}

Ketika tabib atau dukun datang ke rumah orang yang sakit, maka pihak tuan rumah menyambutnya dan mempersilakan masuk. Sebelum ritual dilakukan, maka tuan rumah menghidangkan minuman dan makanan untuk sang tabib atau dukun. Namun terkadang, hidangan minuman dan makanan untuk dukun atau tabib itu disediakan setelah acara selesai. Hal ini tergantung kondisi tuan rumah dan waktu yang tersedia. Sebab, sebagian dukun berpendapat bahwa acara ini harus dilakukan pada waktu pagi hari. Misalnya, Incek Nurbi, ia mengatakan, "pangobatan ini hanyo bisa dibuat pada waktu pagisajo"(pengobatan ini hanya dapat dilakukan pada waktu pagi). Oleh sebab itu, pihak keluarga dan para anggota ritual bergegas untuk melakukannya agar jangan terlambat sehingga matahari naik.

${ }^{15}$ Wawancara dengan Dek Ipin tanggal 15 Desember 2008.

${ }^{16}$ Upah-upah dikenal juga dalam masyarakat Batak Toba dengan sebutan upa-upa. Upa-upa adalah sebuah acara syukuran dengan memberikan suguhan makanan khusus kepada si anak agar Tuhan memberikan kesehatan, kekuatan, dan keselamatan hidupnya. Lihat Doangsa P.L Situmeang, Dalihan Natolu Sistem Sosial Kemasyarakatan Batak Toba (Jakarta: Dian Utama, 2007), h. 134. 
Ritual pengobatan dimulai dengan menyuruh orang yang sakit berbaring di atas tikar atau kasur dengan membuka bajunya, baik pasien itu wanita ataupun laki-laki. Namun, jika wanita yang menjadi pasien, para keluarga atau tamu laki-laki akan menghindar dari tempat pengobatan itu. Sungguh, merupakan sesuatu yang tabu jika laki-laki dewasa ikut dalam acara itu. Namun jika yang sakit seorang laki-laki maka para wanita tidak ditabukan ikut dalam ritual pengobatan. Menurut salah seorang anggota masyarakat Tanjungbalai Asahan, Hasanul Arifin, bahwa ini dimungkinkan pengaruh ajaran Islam yang mengharamkan laki-laki melihat seluruh anggota tubuh wanita yang bukan mahram kecuali muka dan telapak tangan. Sementara aurat laki-laki hanya di antara pusar dan lutut. ${ }^{17}$

Dukun memulai ritualnya dengan memeriksa dan mengumpulkan bahan-bahan pengobatan sesuai dengan urutan yang dinginkannya. Setelah itu ia membaca mantramantra dan menaburkan kemenyan ke dalam dupa. Dengan ditaburkannya kemenyan tersebut, maka ruangan tempat ritual dipenuhi oleh aroma harum semerbak yang mengindikasikan suasana magis, sehingga orang pun larut dalam suasana tersebut.

Untuk Kisik-kisik biasa, tabib atau dukun, mengambil sirih bertemu urat yang sudah dilapis dengan sirih biasa dan ditaburi oleh kapur sirih, pinang, bawang merah, gambir, dan kencur. Lalu ia menancapkan jarum yang diikat dengan benang ke lipatan sirih yang telah disediakan, yaitu berjumlah tiga buah. Selanjutnya, ia mengasapinya dengan asap kemenyan serta membaca mantra-mantra. Ketika sang dukun membaca mantra, maka suasana semakin hening dan diliputi oleh nuansa sakral.

Berikutnya, sang dukun menempelkan daun sirih tersebut ke daun telinga si pasien sembari menjaga agar isi sirih itu tidak tumpah. Ia mengucapkan, "gukhuus sumangat, gukhuus sumangat, gukhuus sumangat, kambali sumungat ka badan." Ia juga membunyikan suara seperti suara tikus ketika ia menyentuh daun kuping pasien.

Ritual selanjutnya, dukun membaca mantra dan mengangkat dupa serta mengelilingkannya ke tubuh si pasien. Ia juga mengangkat mangkok putih yang berisi telur dan mengasapinya dengan asap dupa. Sejenak setelah itu, sang dukun mengambil sedikit beras yang ada di dalam mangkok putih. Selanjutnya, para tamu atau orang-orang yang menyaksikan juga bergiliran mengambilnya. Lalu, setiap orang yang hadir di tempat itu menghitung jumlah butiran beras yang ia ambil dari mangkok putih tersebut. Jika jumlah butiran yang ia ambil itu ganjil, maka ia harus mengulang lagi untuk mengambil tambahannya sehingga jumlahnya genap. Namun, jika beras yang diambil itu sudah genap, maka ia harus menyerahkannya kepada dukun. Ketika semua hadirin sudah menyerahkan kepada dukun, maka dukun pun menaburkan butiran-butiran beras itu kepada pasien seraya mengatakan, "gukhuus sumangat, balek sumangat ka badan."

Setelah itu, dukun memasukkan satu bagian sirih ke mulutnya, sebelumnya terlebih dahulu mencabut jarum dan benang dari sirih itu. Lalu ia mengeluarkannya kembali setelah

\footnotetext{
${ }^{17}$ Dek Ipin, wawancara pada tanggal 15 Desember, 2008.
} 
ia melumatkan dengan giginya. Sirih yang sudah dilumatkan itu di oleskan ke kening pasien, tulang belakang, dada, bahu, siku, lutut, dan ibu jari kaki. Dua bagian sirih yang belum dilumatkan sang dukun disimpan agar pada siang dan sore harinya dapat dilakukan sendiri oleh pihak keluarga.

Ritual berikutnya adalah mengikat benang ke tangan orang yang sakit. Ketika, benang sudah diikatkan, maka selesailah acara Kisik-kisik tersebut. Namun, bagi orang yang sakit demam atau sejenisnya, maka sebelum acara Kisik-kisik dilakukan terlebih dahulu dilakukan acara jungkit-jungkit. Jungkit-jungkit adalah menggosok-gosokkan telur ayam ke badan orang yang sakit dimulai dari kepala (kening), mata, pipi, dan terus ke bawah hingga sampai ke kaki. Selanjutnya, pasien disuruh telungkup dan dukun kembali mengalin telur tersebut mulai dari belakang kepala hingga telapak kaki.

Acara berikutnya adalah memasukkan daun pepaya, kunyit bungle, dan jariango ke dalam mangkok putih yang sudah diisi air. Setelah itu, dukun menggosok-gosokkan ramuan tersebut ke seluruh tubuh pasien dari depan dan dari belakang tubuh pasien sebagaimana dilakukan pada telur ayam.

Ketika telah selesai menggosokkan daun pepaya tersebut, maka dukun mengepulkan asap dupa dengan menghembusnya dan menaburkan kemenyan ke dalam dupa tersebut. Lalu, pasien disuruh duduk menghadap ke dupa. Dalam kesempatan ini dukun kembali membaca mantra-mantranya, lalu asap dupa itu ditangkap sang dukun dan dibawa atau diarahkan ke wajah pasien. Ia terus membaca mantra dan memegang telinga si pasien. Sang dukun pun membunyikan suara seperti suara tikus dengan berulang-ulang. Selanjutnya dupa pun dikelilingkan ke tubuh si pasien.

Bagi pasien yang dideteksi sang dukun mengalami gangguan takono, maka ritual berikutnya diteruskan dengan membaca mantra untuk daun sirih bertemu urat dan mengasapinya dengan asap dupa. Jika harus menggunakan ayam untuk jamuan bagi jin atau orang halus, maka ayam tersebut juga harus diasapi di atas dupa dan diusapkan air yang ada di dalam mangkok putih yang diisi dengan potongan jeruk perut yang sudah dimantrai. Lalu ayam itu diikatkan benang tiga warna di kakinya. Sesudah itu, si pasien pun diikat pada pergelangan tangan kirinya benang tiga warna. Terkadang hanya dengan benang satu warna, yaitu benang putih. Namun, benang putih biasanya disebut tangguh-tangguh, yaitu suatu janji keluarga untuk membelikan atau mewujudkan sesuatu yang diinginkan oleh si pasien.

Setelah selesai acara itu, dilakukan pula acara Kisik-kisik. Jika acara Kisik-kisik telah selesai, maka selesailah rangkaian ritual penyembuhan tersebut. Dengan selesainya acara Kisik-kisik keluarga pun merasa gembira. Mereka berharap penyakit yang diderita anggota keluarganya itu segera sembuh. Namun ketika beberapa hari atau minggu berikutnya pasien tidak sembuh, maka acara yang sama terkadang kembali dilakukan dengan dukun yang berbeda. Mereka beranggapan bahwa mungkin acara pengobatan Kisik-kisik pertama 
itu tidak mujarrab (manjur) untuk mendatangkan sumangat. Sebab itu dilakukanlah acara Kisik-kisik berikutnya.

Setelah acara Kisik-kisik selesai, sang dukun pun pulang dan pihak keluarga memberikan uang kepada sang dukun sebagai imbalan. Namun bagi keluarga acara ini belum selesai, sebab jika pasien tersebut sakit karena takono, maka mereka harus mengantarkan jamuan (sesajen) yang berbentuk daun sirih bertemu urat, atau ayam hidup, atau lancang kuning ke tempat jin atau orang halus itu berada atau pada tempat di mana si-pasien mengganggu jin atau orang halus. Jamuan (sesajen) dan lancang kuning ini merupakan bentuk perdamaian dengan makhluk gaib tersebut. Si pasien dan keluarga mengaku salah dan memberikan bingkisan (cendra mata atau kompensasi) yang dipesankan makhluk gaib itu memalui sang dukun.

\section{Kisik-Kisik dalam Sistem Kepercayaan Masyarakat Tanjungbalai Asahan}

Sistem Kepercayaan Masyarakat Tanjungbalai Asahan

Sebelum diproklamirkan kemerdekaan Indonesia (1945), Tanjungbalai Asahan dipimpin oleh seorang sultan (raja). Oleh sebab itu, sistem pemerintahannya adalah berbentuk kerajaan yang dipimpin seorang raja yang bergelar sultan dibantu oleh para hulu balang dan ketua-ketua kampung. Namun setelah kemerdekaan dan pergolakan rakyat menentang sistem kerajaan para era 40-an, maka daerah ini mengikut sistem Republik dan menjadi salah satu dari daerah tingkat II di Republik Indonesia hingga saat ini. Kelihatannya tidak ada tanda-tanda bahwa daerah ini akan melakukan pemberontakan untuk mengubah sistem pemerintahan yang ada saat ini.

Pada awalnya, sebelum datangnya pengaruh Aceh ke wilayah Tanjungbalai Asahan, agama yang dianut oleh nenek moyang masyarakat Tanjungbalai Asahan adalah agama animisme dan kemungkinan besar juga dipengaruhi juga oleh agama Hindu. Namun setelah terjadinya kontak Raja Simargolang dengan kerajaan Aceh yang datang ke wilayah ini, maka masyarakat Tanjungbalai Asahan memeluk Islam. ${ }^{18}$

Islam yang dianut oleh masyarakat Tanjungbalai Asahan adalah Islam yang umumnya dianut di Nusantara, yaitu dari segi akidah adalah Asy'ariyah ${ }^{19}$ dan dari segi fikih yaitu

\footnotetext{
${ }^{18}$ Lebih jauh tentang informasi tentang Kesultanan Asahan lihat Lucman Sinar Basarshah II, Bangun dan Runtuhnya Kerajaan Melayu di Sumatera Timur (t.t.t.: t.p., t.t.), h. 343.

${ }^{19}$ Saat ini telah terjadi dinamika pemahaman terutama akidah. Sebagian kecil masyarakat Tanjungbalai Asahan telah menganut paham salafisme. Namun aliran Asy'ariyyah tetap saja mendominasi keyakinan masyarakat. Masuknya aliran Salafisme di daerah ini dibawa oleh para dai dari kota Medan dan sekitarnya dan juga para pelajar dari kota Medan menyebabkan terjadinya polarisasi pemahaman keagamaan. Lihat penjelasan lebih jauh di dalam Husnel Anwar, "Cuplikan Sejarah Salafi di Indonesia: Suatu Upaya Penelusuran Awal dari Aran Menuju Deli," (Makalah tidak diterbitkan, 2013), h. 16.
} 
Syâfi'iyah. ${ }^{20}$ Namun, ajaran Islam yang ada di daerah ini masih mengadopsi adat-adat dan ritual-ritual ajaran animisme yang dianut oleh masyarakat sebelumnya. Agama nenek moyang bangsa Indonesia adalah agama primitif di seputar dinamisme dan animisme. ${ }^{21}$ Hal ini sesuai dengan apa yang disebutkan oleh Marvin Harris bahwa dasar dari semua pemikiran agama adalah animisme. ${ }^{22}$ Kendatipun tidak sepenuhnya sependapat tentang tesis Harris, terutama agama-agama wahyu, namun untuk agama-agama non wahyu hal ini sangat memungkinkan.

Ritual-ritual animisme yang masih diterapkan mayarakat Tanjungbalai Asahan tersebut telah mengalami perubahan-perubahan, namun bentuk dan karakteristiknya masih dapat dikenali. Misalnya, ritual tepung tawar, manyonggot, upah-upah, perdukunan, jamu laut, Kisik-kisik dan mistik masih menonjolkan ciri-ciri ini. Secara umum, adat-adat yang berlangsung di masyarakat dipengaruhi oleh kebuadayaan Melayu dan Batak. Memang, sejarah nenek moyang masyarakat Tanjungbalai Asahan adalah berasal dari daratan tanah Batak. Oleh sebab itu, ritual-ritual kepercayaan yang dianut oleh masyarakat Tanjungbalai Asahan tetap mengadopsi ritual-ritual tersebut, seperti upah-upah, perdukunan, dan mistik. Demikian juga acara jamu laut yang ditemukan di wilayah Asahan juga dipahami sebagai elaborasi dari kepercayaan animisme terhadap ruh-ruh gaib yang dianut masyarakat Melayu Kuno. Setelah Islam masuk, kepercayaan ini terus berlangsung hingga saat ini. Namun, sebagian telah melakukan "islamisasi" mantra-mantra dan elaborasi perilaku ritualnya. Islamisasi yang dimaksud di sini bukanlah bermakna bahwa ritual itu telah dipandang sebagai ajaran Islam dalam great tradition, namun yang dimaksud adalah masyarakat tidak lagi memandang ritual itu sebagai ritual animisme an sich.

Sebagian masyarakat awam menganggap ritual-ritual seperti yang telah disebutkan di atas adalah bagian yang berdampingan dengan ajaran Islam, karena secara budaya ritual-ritual itu dipraktikkan oleh para malim (guru), sebagian alim-ulama, dan para haji secara turun temurun. Hal ini sebagaimana yang dipertanyakan kepada salah seorang anggota masyarakat pelaku ritual manyonggot yang bernama Kak Iyong Ramah. Ia mengatakan, "bagininyo, ini kan usaho kito untuk bakhubat. Kitokan disukhuh Allah barubat, bakhubatlah kito. Di sinikan kita mambaco bismillah dan sholawat. Inilah tandonya Islamtu" (begini! Inikan usaha kita untuk berobat. Kita disuruh Allah untuk berobat, maka kita harus berobat. Di dalam acara ini kita membaca bismillah dan shalawat. Ini adalah ciri-ciri Islam).

Di sini terlihat, masyarakat awam memandang islamisasi mantra yang terdapat di dalam ritual-ritual manyonggot, Kisik-kisik, dan sejenisnya dianggap telah menjadikan ritual itu sebagai hal yang berdampingan dengan ajaran Islam. Kendatipun ritual-ritual

\footnotetext{
${ }^{20}$ Lihat Husnel Anwar Matondang, Kewajiban Tuhan, h. 87.

${ }^{21}$ Suwarno Imam S., Konsep Tuhan, Manusia, Mistik, dalam Berbagai Kebatinan Jawa (Jakarta: RajaGrafindo Persada, 2005), h. 1.

${ }^{22}$ Marvin Harris, Why We Became Religious and the Evolution of the Spirit World: Study of Religion (t.t.p.: t.p., 2008), h. 16.
} 
tersebut pada ajaran animisme merupakan suatu bentuk ibadah (penyembahan) kepada makhluk gaib, namun masyarakat Tanjungbalai menganggapnya bukan lagi bagian ibadah animisme, tetapi bagian dari kepercayaan masyarakat Muslim terhadap magis. Hal ini dibuktikan pula bahwa acara seperti tepung tawar kerap dilakukan di masjid atau mandokhsah (tempat salat) dan tempat-tempat pendidikan Islam. Misalnya, upahupah dan tepung tawar atas keberangkatan haji, khataman al-Qur'an dan kepindahan guru mengaji. Demikian pula, ritual Kisik-kisik dan jamu laut dilakukan oleh para lebai dan orang-orang yang telah melakukan suluk dalam tarekat tertentu.

Konsep-konsep seperti adanya jin, setan, dan ruh yang ditemukan di dalam ajaran Islam (great tradition) turut mengukuhkan keberadaan ritual-ritual seperti Kisik-kisik, manyonggot, takono, jamu laut, dan perdukunan di dalam kepercayaan masyarakat. Sebab keseluruhan ajaran itu berintikan adanya kontak antara dunia lahir dengan dunia gaib. Ritual-ritual tersebut umumnya membujuk kekuatan gaib untuk berdamai dengan manusia. Oleh sebab itu, manusia selalu dipandang sebagai makhluk yang lemah dibandingkan dengan kekuatan-ketuan gaib tersebut. Dengan demikian, manusia menjadi korban dan kerap pula menjadi sosok yang harus mengeluarkan jamuan sebagai konpensasi ketika berdamai dengan ruh atau jin. Kelemahan itu juga sering ditunjukkan oleh kelompok masyarakat yang pergi ke dalam hutan atau ke daerah yang dianggap rawan dan dihuni orang halus atau jin. Mereka mengucapkan, "Tabek dotok, cucu numpang lewat." Padahal, tidak diketahui dari penduduk lokal kasus adanya jin yang meminta maaf kepada manusia, baik secara langsung mapun melalui orang atau dukun yang kesurupan jin. Namun keselamatan diri dan ketakutan terhadap makhluk halus yang tidak bisa diprediksikan menjadikan mereka harus melakukan ucapan-ucapan tertentu untuk menghindarinya.

Perhatian besar kepada akibat yang ditimbulkan secara gaib kepada seseorang dapat pula dilihat dari batasan-batasan yang boleh dan tidak boleh dilakukan masyarakat yang disebut dengan pantang. Seperti, pantang membawa anak-anak ke luar rumah pada tengah hari dan senja hari. Sebab, waktu-waktu itu diyakini banyak makhluk halus dan jin yang berkeliaran di luar rumah. Jika pantang tersebut dilanggar maka kemungkinan besar si anak akan disambar jin atau keteguran. Pantang juga dapat mengakibatkan sial, seperti pantang anak gadis duduk sambil makan di tengah-tengah pintu rumah (bendulan), hal itu akan berakibat susah mendapatkan jodoh. Demikian juga pantang yang mengakibatkan penyakit pada fisik (jasad) seperti pantang duduk di atas bantal yang digunakan untuk tidur, sebab akan berakibat penyakit bisul.

Dalam pada itu, pada hakikatnya, masyarakat juga bersikap oportunitas terhadap makhluk-makhluk gaib. Mereka tidak melakukan ritual-ritual tersebut kecuali ada keinginan yang menguntungkan mereka secara fisik dan psikis. Misalnya, karena ingin sembuh, ingin mendapatkan tangkapan ikan yang banyak di laut. Tidak ada ritual yang khusus hanya untuk memuja terhadap makhluk-makhluk gaib itu selain untuk mendapatkan keuntungan dari makhluk-makhluk gaib tersebut. Oleh sebab itu, ritual-ritual magis ini pasti memiliki 
tujuan-tujuan khusus untuk kepentingan, yaitu keamanan dan keselamatan. Berdasarkan hal ini, maka ritual Kisik-kisik tersebut tidak terbantahkan sebagai gambaran yang diberikan oleh Bronislaw Malinowski, yakni masyarakat melakukan ritual magis karena ingin memenuhi sebagian dari tujuh bidang kebutuhan dasar masyarakat, yaitu metabolisme, reproduksi, kesenangan pisik, keamanan, gerakan, pertumbuhan, dan kesehatan. ${ }^{23}$

Berdasarkan penjelasan di atas, sistem kepercayaan masyarakat Muslim Tanjungbalai Asahan adalah bersumber dari Islam yang ditemukan di dalam kitab suci al-Qur'an (seperti kepercayaan kepada jin, ruh, dan setan) dan juga Islam yang telah menemui pengaruh dan adaptasi dengan kepercayaan serta ritual-ritual masyarakat pra Islam, yaitu animisme. Sistem kepercayaan ini akan terus bertahan dalam waktu yang akan datang selama tidak ada upaya-upaya sistematis yang mampu untuk merubahnya. Sebab kepercayaan ini telah menyatu di dalam pemikiran dan perilaku masyarakat Muslim, sehingga masyarakat tidak melihat bahwa hal ini sesuatu yang bertentangan dengan ajaran Islam. Sebagaimana yang dikatakan oleh Ronald A. Lukens Bull, budaya itu tidak saja merupakan perilaku tetapi juga pemikiran, ${ }^{24}$ maka pada masyarakat Tanjungbalai Asahan kedua unsur itu telah tertanam di dalam pemikiran dan perilaku mereka sehingga menciptakan suatu budaya yang mapan. Tradisi dan keyakinan ini akan tetap menjadi sistem kepercayaan masyarakat dalam menghadapi ketidaktahuan dan ketakutan mereka terhadap pengaruh makhluk-makhluk gaib. Jika dilihat dari karakter magis Bronislaw Malinowski, maka terdapat perbedaan masyarakat Tanjungbalai Asahan dengan orang-orang Tabriand yang menjadi objek kajiannya. Bagi orang-orang Tabriand menangkap ikan di danau sangat dapat diramalkan, namun menangkap ikan di laut lepas tidak dapat diramalkan dan berbahaya, di sinilah ritual magis mereka lakukan. ${ }^{25}$ Ini artinya orang-orang Tabriand seperti yang dikatakan Bronislaw Malinowski adalah orang cerdik, berperhitungan, dan masuk akal, namun bagi masyarakat Tanjungbalai Asahan dalam konteks magis dilakukan tidak hanya dasar-dasar ketidaktahuan, tetapi sebuah kepercayaan terhadap hal-hal gaib yang berusaha mendampingkannya dengan ajaran agama Islam. Kendatipun magis bukan dipahami sebagai agama seperti yang dijelaskan Harris, ${ }^{26}$ namun pada masyarakat Tanjungbalai, terjadi adaptasi kepercayaan ini dengan agama, seperti islamisasi mantra-mantra yang mengacu kepada ayat-ayat al-Qur'an. Ini menjadikan konsep magis yang dipraktikkan oleh masyarakat Tanjungbalai Asahan sebagai bentuk baru dalam konsep magis yang dipahami para antropolog di Barat selama ini.

\section{Keberadaan Kisik-Kisik dalam Masyarakat Tanjungbalai Asahan}

Sebagaimana yang telah disebutkan sebelumnya, Kisik-kisik merupakan sebuah

\footnotetext{
${ }^{23}$ Malinowski, A. Scientific Theory of Culture, h. 91.

${ }^{24}$ Ceramah dalam mata Kuliah Teori-teori Agama pada Program Pascasarjana IAIN Sumatera Utara Medan.

${ }^{25}$ Lihat lebih jauh uraian Gellner, "Pendekatan Antropologis," h. 27.

${ }^{26}$ Marvin Harris, Why We Became Religious and the Evolution of the Spirit World, h. 17.
} 
sistem kepercayaan masyarakat Tanjungbalai Asahan yang terkait dengan penyembuhan. Secara lebih khusus dapat dikatakan bahwa Kisik-kisik merupakan upaya untuk memanggil atau mengembalikan sumangat (ruh) ke dalam tubuh seseorang. Konsep tentang roh sangat kompleks dan sukar untuk dijelaskan. Sebab tidak ada literatur yang pernah ditulis di wilyah ini tentang ruh dan tidak ada penjelasan ditemukan yang dapat memberikan informasi secara lengkap. Memang di dalam ajaran Islam, tepatnya di dalam al-Qur'an disebutkan (artinya), "Mereka bertanya kepadamu wahai Muhammad tentang ruh. Katakanlah bahwa ruh itu adalah urusan Tuhanmu" (Q.S. al-Isrâ'/17: 85).

Namun demikian, di dalam Islam tidak dikenal adanya konsep tentang sumangat. Menurut Dek Ipin, salah seorang anggota masyarakat Tanjungbalai Asahan, mengatakan bahwa sumangat itu adalah suatu daya atau kekuatan yang apabila ia ada pada diri seseorang, maka orang tersebut akan aktif, kreatif, dan antusias melakukan segala pekerjaan dan ikhtiar. Namun ketika sumangat itu pergi atau hilang, maka orang tersebut tetap hidup namun tidak memiliki gairah untuk melakukan kegiatan apapun secara dinamis. Dengan demikian, hidup tanpa sumangat adalah kehidupan negatif dan dipandang buruk. Kehidupan tanpa gairah ini merupakan kematian karakter kedinamisan seseorang. Oleh sebab itu, masyarakat tidak menginginkan hal itu terjadi pada dirinya dan keluarganya. Ketidakinginan mereka kepada kehidupan negatif tersebut menyebabkan mereka melakukan ritual-ritual Kisik-kisik. Kendatipun ritual ini dilandasi ketidakmampuan dan ketidaktahuan mereka terhadap kekuatan makhluk gaib dan hal-hal gaib, namun ia telah menjadi keyakinan magis yang sangat mengakar.

Jika dipandang dari tujuan ritual Kisik-kisik, maka maksud utama yang ingin dicapai bukanlah ritual itu sendiri melainkan implikasi (manfaat) dari ritual itu, yaitu munculnya gairah dan motivasi dari orang yang sakit untuk sembuh dan kembali bekerja dan beraktivitas agar dirinya tidak menjadi beban keluarga atau masyarakat. Dengan kata lain, ritual ini dilakukan untuk mengembalikan fungsi seseorang secara normal untuk aktif di tengahtengah keluarga, komunitas, dan masyarakatnya. Jika ia seorang kepala keluarga, maka tujuan yang terselip dari keluarga melakukan acara itu adalah agar tanggungjawabnya terhadap keluarga dan masyarakat kembali dapat dipenuhinya. Ketika keinginan untuk sehat dari penyakit telah muncul dalam diri seserorang maka ia akan berusaha untuk sembuh dengan segala daya dan upayanya. Ini juga menjadi bukti bahwa masyarakat Tanjungbalai memahami adanya hubungan kejiwaan dengan kesehatan. Masalah kejiwaan selalu mempengaruhi fisik manusia. Oleh sebab itu, ritual magis ini merupakan sebuah dorongan psikologis. Namun tujuan ini dibungkus dengan tradisi magis yang ada di dalam masyarakat sebagai sebuah kesadaran supranatural yang telah melekat di dalam budaya dan pemikiran umum masyarakat. Di sinilah akhirnya nilai-nilai sakralitas ritual Kisik-kisik tersebut terlembaga di dalam sistem kepercayaan masyarakat Tanjungbalai Asahan. Berdasarkan deskripsi di atas, maka ritual ini dipahami masyarakat Tanjungbalai Asahan memiliki manfaat lahiriah dan manfaat batiniah. Dengan demikian, Kisik-kisik termasuk sebuah manipulasi ritual 
magis untuk tujuan-tujuan individu dan kelompok keluarga dan masyarakat agar memiliki kreativitas, kedinamisan, dan etos kerja.

Dipahami pula bahwa keuntungan untuk melanggengkan ritual ini di dalam sistem kepercayaan masyarakat dapat dilihat dari dua sudut pandang. Pertama, sudut pandang dukun sebagai penggerak ritual. Dukun, sangat diuntungkan untuk melanggengkan ritual ini. Sebab, mereka akan mendapatkan imbalan-imbalan material dari ritual-ritual tersebut. Setiap kali dilakukan ritual Kisik-kisik, maka mereka akan diberikan imbalan uang dan penajam (bingkisan untuk penutup perobatan). Kendatipun pembayaran melakukan ritual tersebut tidak terlalu besar, namun hal itu cukup membantu para dukun dalam memenuhi kebutuhannya. Pada konteks terakhir inilah teori Marx dapat dipergunakan sebagai pisau analisis.

Pertanyaan dapat dilanjutkan, "mengapa para dukun Kisik-kisik hanya perempuan tua?" Jawabannya dilihat dari sudut pandang Marx adalah karena mereka yang berjenis kelamin perempuan dalam usia yang sudah sangat tua dan tidak lagi produktif untuk melakukan kegiatan-kegiatan ekonomis praktis harus mempertahankan kehidupannya dengan memanfaatkan kharismanya dan kepercayaan kepada magis yang ada di dalam masyarakat. Hal itu diperkuat, karena pada umumnya, dukun Kisik-kisik adalah kelompok yang memiliki ekonomi lemah. Hal ini telah menjadi fakta dan realitas objektif yang terjadi pada dukun-dukun Kisik-kisik di masyarakat Tanjungbalai Asahan. Di antara contohnya adalah Mak Obak. Ketika ia ditinggal mati suaminya dan tidak mampu lagi untuk mengambil daun nipah ke hutan guna dijual kepada masyarakat yang membutuhkan, maka ia mengkhususkan diri menjadi dukun. Demikian pula dengan Kak Acom, ia ditinggal mati suaminya yang menopang kehidupannya secara penuh selama ini. Adapun kasus Incek Nurbi juga tidak jauh berbeda, ia menjadi dukun Kisik-kisik karena untuk menopang keluarganya yang berekonomi lemah dan anaknya yang mendapat gangguan jiwa.

Kedua, dapat ditinjau dari masyarakat pengguna jasa dukun. Bagi orang yang memiliki kecerdasan, sangat sukar memahamijika ada suatu kegiatan yang dilakukan oleh masyarakat secara berulang-ulang dan dengan kesadaran tanpa ada tujuan yang bermanfaat untuknya. Namun, tujuan itu terkadang ada yang bersifat ukhrawi dan ada yang bersifat duniawi. Bagi masyarakat Muslim Tanjungbalai tujuan melakukan salat misalnya secara ideal tidak memiliki tujuan duniawi, tujuannya adalah untuk mendapatkan keuntungan akhirat, namun ritual-ritual seperti Kisik-kisik adalah memiliki tujuan duniawi, yaitu kesembuhan dan munculnya motivasi dan kesadaran dari orang yang sakit agar ia harus sembuh dan beraktivitas sebagaimana biasanya.

\section{Kesimpulan dan Saran}

Upacara Kisik-kisik untuk memanggil atau mengembalikan sumangat (ruh) dijadikan sebagai ritual magis untuk kesembuhan. Sumangat itu dapat kembali lagi ke dalam jasad 
penderita ketika ia diseru atau dibujuk untuk kembali dengan ritual Kisik-kisik dan sejenisnya. Masyarakat Tanjungbalai Asahan sebagai pelaku ritual Kisik-kisik mempercayai bahwa penyakit yang diderita oleh manusia selalu dipahami dalam dua sisi yang saling mempengaruhi. Pertama, penyakit pada jasad dapat mempengaruhi jiwa (batin/ruh). Kedua, penyakit pada jiwa (batin) dapat pula mempengaruhi kesehatan jasad (badan).

Ritual Kisik-kisik tersebut berawal dari kepercayaan animisme yang menjadi anutan nenek moyang orang-orang Tanjungbalai Asahan. Namun ia tetap dipraktikkan kendatipun mereka telah memeluk Islam, di dalam Islam konsep tentang sumangat itu tidak ditemukan. Ini menunjukkan bahwa Kisik-kisik tidak dijadikan sebagai pengamalan agama Islam, namun hanya sebagai ritual magis. Namun magis ini telah diadaptasikan dengan ajaranajaran Islam, khususnya tentang mantra-mantra yang dibaca. Dari indikasi-indikasi sosial bahwa ritual ini tetap dilanggengkan para dukun karena mereka mendapat keuntungan dari ritual-ritual seperti ini. Setiap kali mereka melaksanakannya, maka mereka mendapat imbalan yang memadai untuk menopang kehidupan mereka yang miskin. Ritual Kisikkisik ini diprediksikan akan tetap berlangsung karena telah menjadi bagian dari budaya masyarakat, yaitu hidup didalam praktik dan exist di dalam pemikiran mereka. Namun dapat juga diprediksikan adanya perubahan-perubahan dalam menerapkan ritual tersebut karena terkait dengan adaptasi-adaptasi dengan ajaran Islam dan kondisi masyarakat.

Dari hasil kajian ini dan konsepsi ideal yang harus ada pada seorang Muslim, disarankan agar ketidaktahuan atau ketidakterlihatannya makhluk halus atau jin tidak mengharuskan seorang Muslim melakukan ritual di luar ritual yang syariatkan di dalam Islam. Terlebih lagi, jika ritual itu merupakan warisan dari ritual kesyirikan dan kepercayaan animisme. Konsep tauhid rubûbiyyah mengharuskan seorang Muslim bertawakal, menyerahkan diri, dan pasrah hanya kepada Allah sebagai pengatur, penyembuh, dan penyelamat manusia. Selanjutnya, konsep ulûhiyyah mengharuskan seorang Muslim untuk melakukan ritual hanya kepada Allah dan dengan cara yang ditetapkan syariat yang diturunkanNya. Dua prinsip tauhid ini, telah dilanggar oleh para pelaku ritual Kisik-kisik di dalam masyarakat Tanjungbalai Asahan. Oleh sebab itu, tujuan-tujuan yang ingin dicapai seperti untuk mengembalikan gairah kesembuhan dan etos kerja sebenarnya ditemukan di dalam ajaran Islam sendiri. Karena itu, masyarakat Tanjungbalai disarankan untuk mengkaji ajaran Islam lebih dalam tentang masalah ini yang telah dipersiapkan Allah di dalam alQur'an dan Sunah Nabi-Nya.

\section{Pustaka Acuan}

Arsyad, Mohamad. Tabal Mahkota Negeri Asahan. t.t.p.: t.p., 1933.

Basarshah II, Luckman Sinar. Bangun dan Runtuhnya Kerajaan Melayu di Sumatera Timur. t.t.t.: t.p., t.t. 
Bowen, John R., Religions in Practice: an Approach to the Anthropology of Religion. Amerika: Washington University in St. Louis, t.t.

Gellner, David C. "Pendekatan Antropologis," dalam Peter Connolly (ed.). Aneka Pendekatan dalam Studi Agama. Amerika: Continuum, 1999.

Harris, Marvin. Why We Became Religious and The Evolution of the Pririt World, Study of Religion. t.t.p.: t.p., 2008.

Imam S., Suwarno. Konsep Tuhan, Manusia: Mistik dalam Berbagai Kebatinan Jawa. Jakarta: RajaGrafindo Persada, 2005.

Lukens Bull, Ronald A. "Between Text and Practice: Considerations in The Antrophologycal Study of Islam," dalam Marburg Journal of Religion. Vol. 4, No. 2, December 1999.

Malinowski, A. Scientific Theory of Culture Other Essays. Amerika: Universiti of North California Press, 1994.

Matondang, Husnel Anwar. "Cuplikan Sejarah Salafi di Indonesia: Suatu Upaya Penelusuran Awal dari Aran Menuju Deli." Makalah tidak diterbitkan, 2013.

Matondang, Husnel Anwar. Kewajiban Tuhan: Pemikiran Kontroversial Ulama Tanjungbalai Asahan Syaikh Ismail Abdul Wahhab. Medan: LP2IK, 2004.

Siahaan, Nalom. Adat Dalihan Natolu: Prinsip dan Pelaksanaannya. Jakarta: Tulus Jaya, 1982.

Situmeang, Doangsa P.L. Dalihan Natolu: Sistem Sosial Kemasyarakatan Batak Toba. Jakarta: Dian Utama, 2007. 